\title{
Study on Intelligent Data Algorithms Implemented in Wearable for Sports Applications
}

\author{
N.Nithya ${ }^{\mathrm{a}, 1}$ and G.Nallavan ${ }^{\mathrm{b}}$ \\ ${ }^{a}$ Research Scholar, Dept of AST\&T,TNPESU, Chennai \\ ${ }^{b}$ Assistant Professor, Dept of AST\&T, TNPESU, Chennai
}

\begin{abstract}
Technological transformation is unlocking new opportunities in wearable devices used in sports application. Nowadays training the sports involves the use of integrating smart sensors, cameras, internet of things and intelligent data algorithms into a device which is wearable making the players to achieve their maximum performance. These smart devices replace the coach and manage all aspects of technical training except for the physical training given by the real coach. This paper provides a comprehensive study on the intelligent data analysis made on the data acquired from sensors to give a meaningful sense to it. The smart training methods employed currently in various sports are identified and presented. The future directions in this area of research are also presented.
\end{abstract}

Keywords: Wearable devices, intelligent data algorithms, sensors, technical training, sports

\section{Introduction}

The technological boom has influenced in all areas of human life. Smart devices have changed the way of looking the world. Sports field is not an exception. Wearables take new dimension in monitoring sports activities of the player. These devices incorporated with smart algorithms help the player to understand his performance and help him to compete to next level. Due to developments in internet and cloud services the collected data from sensors can be worked in a detailed manner. Here clever algorithms can be applied which extracts the features, train the data set and can be tested to verify its accuracy. With these resources the devices now become smart Artificial Intelligent (AI) devices which will help the player to train himself and achieve better results. Section 2 discusses the role of wearables in smart training. Section 3 briefs the sensors that are commonly used in devices. Section 4 summarizes the intelligent approach used in the sports wearables and the results obtained. Section 5 lists the challenges faced and section 6 concludes with the limitations and identifies the scope of futureresearch.

\footnotetext{
${ }^{1}$ Nithya .N, Research Scholar, Dept of AST\&T,TNPESU, Chennai;

E-mail: nnithyapanimalarece@gmail.com.
} 


\section{Wearables in SportsTraining}

The role of coach for a player is very important. Unfortunately all aspirant players do not get their dream coach. Sometimes financial support also poses some problem. So, wearable technology could reduce this burden by providing solution to the above problem. Intelligent algorithms incorporated in these devices gives clues to the player so that he can understand his game profile and take necessary steps to correct and achieve histarget.

Two important sections in wearable device are,

\section{Hardware}

a. Sensor selection

b. Noise removal

c. Communication to the decision making subsystem

2.Software which takes decision based on acquired signals.

The tasks performed during training require physical effort and it is a continuous process where the ultimate goal is to improve the perfection in the game played. The various stages involved in sports training are,

- Data acquisition

- Intelligent dataanalysis

- Assessment

- Targetrealization

The flow diagram for the sports training is shown in figure 1,

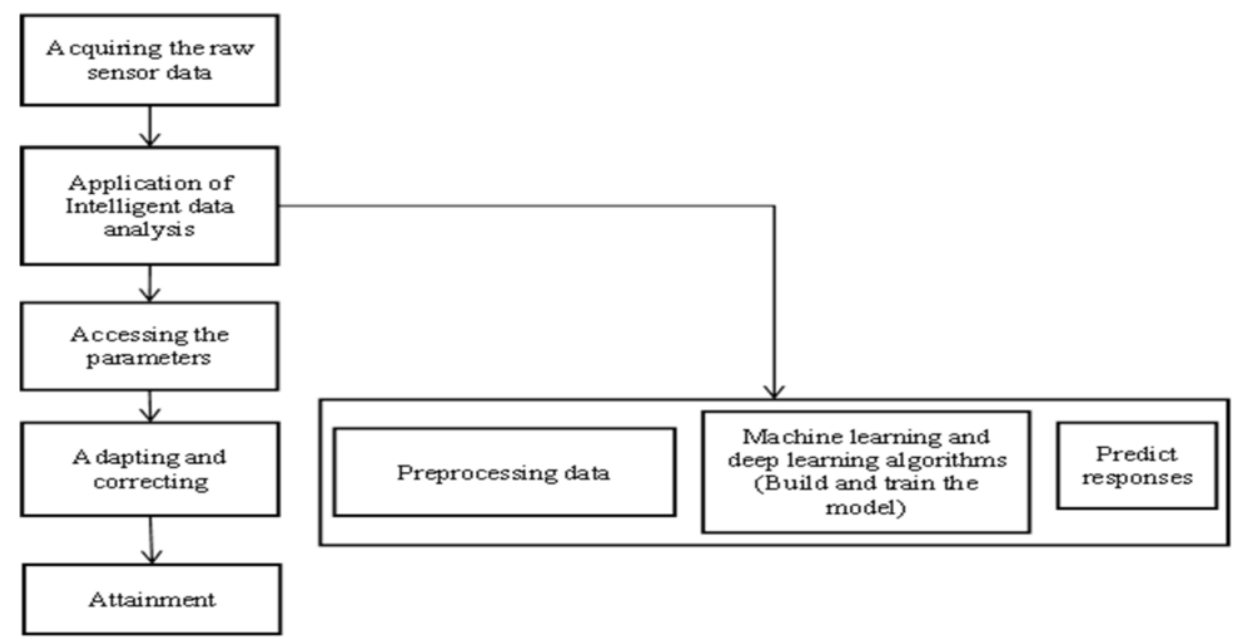

Figure 1. Flow diagram for sports training 


\section{Sensors}

The important consideration for developing a wearable device is the selection of sensors. The sensors should be reliable, small in size, light in weight and durable. The data's from sensors can be used in activity recognition i.e. understand the body kinematics and movement parameters. The machine learning algorithms can be applied on the collected data's to bring out predictions. To get best results the user has to select the suitable algorithm to get the desired insight. The algorithm can be supervised or unsupervised. But all data processing algorithms cannot run on the device itself due to lack of its computational capacity, memory constraints and power back up. So with Bluetooth or wireless module the data's can be transported to a mobile or cloud services where intelligent algorithms can be performed to aid the player in decision making. This virtual coach assists the player in his training replacing the actual trainer. The various sensors deployed in sports wearables are inertial measurement unit which involves accelerometer, gyroscope and magnetometer, pressure sensor array, force sensor, motion sensor etc.

\section{Intelligent data algorithms in sports}

Intelligent data algorithms and data set can provide a method to analyze the performance parameter of an athlete and can improve his training plan to achieve the best results. Table 1 summarizes the information such as the name of the sport, the sensors used, the features detected, the goal, the classification algorithm and the accuracyobtained.

Table 1.Studies identified in sports wearable sensors with intelligent approach

\begin{tabular}{|c|c|c|c|c|c|c|}
\hline Ref & Sport & Sensor & Features & Aim & Approach & Result \\
\hline [1] & $\begin{array}{c}\text { Basket } \\
\text { ball }\end{array}$ & $\begin{array}{l}\text { Motion } \\
\text { sensor }\end{array}$ & $\begin{array}{c}\text { Body } \\
\text { acceleration } \\
\text {, Gesture }\end{array}$ & $\begin{array}{l}\text { Automatic } \\
\text { recognition } \\
\text { of basketball } \\
\text { training type }\end{array}$ & $\begin{array}{l}\text { Support Vector } \\
\text { Machine (SVM) }\end{array}$ & $\begin{array}{l}99.5 \% \\
\text { accuracy } \\
\text { with SVM } \\
\text { algorithm or } \\
\text { activity } \\
\text { recognition }\end{array}$ \\
\hline [2] & $\begin{array}{l}\text { Basket } \\
\text { ball }\end{array}$ & $\begin{array}{l}\text { Acceleromete } \\
\mathrm{r} \text { and } \\
\text { Gyroscope }\end{array}$ & $\begin{array}{l}\text { Arithmetic } \\
\text { mean and } \\
\text { Standard } \\
\text { deviation }\end{array}$ & $\begin{array}{l}\text { Classify the } \\
\text { action of } \\
\text { players }\end{array}$ & $\begin{array}{l}\text { k-Nearest } \\
\text { Neighbours (k- } \\
\text { NN),Random } \\
\text { Forests }\end{array}$ & $\begin{array}{l}\text { Random } \\
\text { Forests was } \\
\text { more } \\
\text { accurate } \\
\text { than k-NN }\end{array}$ \\
\hline [3] & Fitness & $\begin{array}{l}\text { Multiple } \\
\text { acceleration } \\
\text { sensor on } \\
\text { several parts } \\
\text { of } \\
\text { body/distribut } \\
\text { ed across } \\
\text { body }\end{array}$ & $\begin{array}{l}\text { Mean, } \\
\text { Maximum, } \\
\text { Minimum, } \\
\text { Range, } \\
\text { Standard } \\
\text { deviation, } \\
\text { Root mean } \\
\text { square }\end{array}$ & $\begin{array}{l}\text { Examine the } \\
\text { participant } \\
\text { performance } \\
\text { on collected } \\
\text { data set from } \\
\text { a smart wrist } \\
\text { wearable } \\
\text { device }\end{array}$ & $\begin{array}{l}\text { k-NN, Linear } \\
\text { SVM, Naïve } \\
\text { Bayes with } \\
\text { Gaussian kernel \& } \\
\text { Bernoulli(NB),SV } \\
\text { M polynomial, } \\
\text { Decision Tree } \\
\text { (DT), Long Short- } \\
\text { term Memory } \\
\text { (LSTM) }\end{array}$ & $\begin{array}{l}\text { LSTM is } \\
\text { best with an } \\
\text { accuracy of } \\
92.5 \%\end{array}$ \\
\hline
\end{tabular}




\begin{tabular}{|c|c|c|c|c|c|c|}
\hline [4] & Fitness & $\begin{array}{l}\text { Acceleromete } \\
\mathrm{r} \text { and } \\
\text { Gyroscope, } \\
\text { Pulse rate } \\
\text { sensor }\end{array}$ & $\begin{array}{l}\text { Mean, } \\
\text { Standard } \\
\text { Deviation }\end{array}$ & $\begin{array}{l}\text { Classify the } \\
\text { indoor } \\
\text { exercise } \\
\text { activity such } \\
\text { as biceps } \\
\text { curl, Row, } \\
\text { Pushup, Sit } \\
\text { up, Squat and } \\
\text { Triceps curl }\end{array}$ & k-NN,SVM, DT & $\begin{array}{l}95.3 \% \\
\text { accuracy for } \\
\text { activity } \\
\text { recognition } \\
\text { and } 99.4 \% \\
\text { for repetition } \\
\text { count }\end{array}$ \\
\hline [5] & Running & $\begin{array}{l}\text { Wireless } \\
\text { sensor } \\
\text { network } \\
\text { deployed in } \\
\text { the area of } \\
\text { training. } \\
\text { MTS } 400 \\
\text { sensor board, } \\
\text { Crossbow } \\
\text { MOTE2 IPR } \\
\text { 2400 }\end{array}$ & $\begin{array}{l}\text { Mean, } \\
\text { Standard } \\
\text { Deviation }\end{array}$ & $\begin{array}{l}\text { Develop a } \\
\text { prototype to } \\
\text { support } \\
\text { athlete with } \\
\text { ambient } \\
\text { intelligent } \\
\text { algorithms }\end{array}$ & $\begin{array}{l}\text { k-NN, SVM, } \\
\text { Spline } \\
\text { Interpolation }\end{array}$ & $\begin{array}{l}\text { Classificatio } \\
\mathrm{n} \text { system } \\
\text { achieves and } \\
\text { accuracy of } \\
80 \% \text { in } \\
\text { spline } \\
\text { interpolation }\end{array}$ \\
\hline [6] & Soccer & $\begin{array}{l}\text { Data form } \\
\text { video } \\
\text { recordings }\end{array}$ & $\begin{array}{l}\text { Mean, } \\
\text { Maximum, } \\
\text { Minimum, } \\
\text { Standard } \\
\text { deviation }\end{array}$ & $\begin{array}{l}\text { Classify } \\
\text { athlete } \\
\text { position and } \\
\text { predict the } \\
\text { number of } \\
\text { goals scored } \\
\text { in the game }\end{array}$ & $\begin{array}{l}\text { SVM, RF, Linear } \\
\text { Regression (LR) }\end{array}$ & $\begin{array}{l}82 \% \\
\text { accuracy is } \\
\text { achieved in } \\
\text { RF and LR }\end{array}$ \\
\hline [7] & Football & $\begin{array}{l}\text { Data from } \\
\text { data set at } \\
\text { Tottenham } \\
\text { Hotspur } \\
\text { Football club }\end{array}$ & $\begin{array}{l}\text { Maximum, } \\
\text { Minimum }\end{array}$ & $\begin{array}{l}\text { To predict } \\
\text { the recovery } \\
\text { time after } \\
\text { injury } \\
\text { without } \\
\text { official } \\
\text { diagnosis }\end{array}$ & $\begin{array}{l}\text { SVM Radial basis } \\
\text { function (RBF) } \\
\text { kernel and } \\
\text { polynomial } \\
\text { kernel, Gaussian } \\
\text { process with RBF } \\
\text { and Laplace } \\
\text { kernel, Artificial } \\
\text { Neural Network } \\
\text { (ANN) }\end{array}$ & $\begin{array}{l}\text { Accuracy for } \\
\text { SVM- } \\
98.43 \% \text {, } \\
\text { Gaussian } \\
\text { process- } \\
97.4 \% \text {,ANN } \\
-98 \%\end{array}$ \\
\hline [8] & $\begin{array}{l}\text { Table } \\
\text { Tennis }\end{array}$ & IMU sensor & $\begin{array}{l}\text { Mean, SD, } \\
\text { Skewness, } \\
\text { Kurtosis }\end{array}$ & $\begin{array}{l}\text { To detect and } \\
\text { classify the } \\
\text { stroke in } \\
\text { table tennis }\end{array}$ & $\begin{array}{l}\text { SVM linear, SVM } \\
\text { RBF, RF, k-NN }\end{array}$ & $\begin{array}{l}\text { SVM linear- } \\
\text { 95.6\%, SVM } \\
\text { RBF-96.7\%, } \\
\text { RF-95.7\%, } \\
\text { kNN-94.7\% }\end{array}$ \\
\hline [9] & Tennis & $\begin{array}{l}\text { Video } \\
\text { recordings }\end{array}$ & $\begin{array}{l}3 \text { layer } \\
\text { LSTM } \\
\text { network }\end{array}$ & $\begin{array}{l}\text { Classifies the } \\
\text { activities in } \\
\text { tennis shots }\end{array}$ & LSTM & $\begin{array}{l}81.23 \% \text { to } \\
88.16 \%\end{array}$ \\
\hline$[10]$ & $\begin{array}{l}\text { Volley } \\
\text { ball }\end{array}$ & $\begin{array}{l}\text { IMU, EMG } \\
\text { sensors and } \\
\text { video } \\
\text { cameras }\end{array}$ & Mean, SD & $\begin{array}{l}\text { Identifying } \\
\text { and } \\
\text { classifying } \\
\text { the not } \\
\text { allowed } \\
\text { moves and } \\
\text { providing } \\
\text { feedback in } \\
\text { training } \\
\text { sessions }\end{array}$ & LSTM & $\begin{array}{l}\text { F1 score of } \\
0.74 \text { for } \\
\text { labels with } 2 \\
\text { classes }\end{array}$ \\
\hline
\end{tabular}




\begin{tabular}{|c|c|c|c|c|c|c|}
\hline [11] & $\begin{array}{l}\text { Weight } \\
\text { lifting }\end{array}$ & IMU & $\begin{array}{l}\text { Mean, } \\
\text { Variance, } \\
\text { SD }\end{array}$ & $\begin{array}{l}\text { Classifying } \\
\text { the weight } \\
\text { lifting } \\
\text { exercises }\end{array}$ & $\begin{array}{c}\text { SVM, Linear } \\
\text { Discriminant } \\
\text { Analysis (LDA) }\end{array}$ & $\begin{array}{c}94.36 \% \\
\text { accuracy in } \\
\text { SVM }\end{array}$ \\
\hline$[12]$ & Cricket & $\begin{array}{l}\text { Recorded } \\
\text { videos }\end{array}$ & - & $\begin{array}{l}\text { Develop AI } \\
\text { training } \\
\text { system to be } \\
\text { used as a } \\
\text { coach for } \\
\text { trainees to } \\
\text { become } \\
\text { expert in } \\
\text { batting, } \\
\text { bowling and } \\
\text { fielding }\end{array}$ & Fuzzy, ANN & $\begin{array}{l}\text { Good } \\
\text { classification } \\
\text { accuracy }\end{array}$ \\
\hline [13] & Cricket & $\begin{array}{l}\text { Data form } \\
\text { IPL matches }\end{array}$ & Mean, SD & $\begin{array}{l}\text { To identify } \\
\text { the best set of } \\
\text { attributes in } \\
\text { the player in } \\
\text { the match } \\
\text { played }\end{array}$ & SVM & $81 \%$ \\
\hline$[14]$ & Golf & $\begin{array}{l}\text { Strain gauge } \\
\text { sensor, 3-axis } \\
\text { accelerometer } \\
\text { and 3-axis } \\
\text { gyroscope }\end{array}$ & - & $\begin{array}{l}\text { Investigate } \\
\text { Golf swing } \\
\text { data } \\
\text { classification } \\
\text { method }\end{array}$ & $\begin{array}{l}\text { Convolutional } \\
\text { Neural Network } \\
(\mathrm{CNN}), \text { SVM }\end{array}$ & $\begin{array}{l}95 \% \text { of } \\
\text { accuracy is } \\
\text { achieved in } \\
\text { deep CNN } \\
\text { than SVM } \\
\text { which is } \\
86.8 \%\end{array}$ \\
\hline
\end{tabular}

\section{Challenges}

Plenty of research is open in the field of sports training. Some of the challenges to be addressed are:

1. The authors have shown results conducted with certain method and approach and tabulated their findings. But they are not aware whether these methods will be adopted by all athletes over long term. So the researchers can share their views and results with the real world. Can interact with professional athlete and conduct more experiments and provide a wider scope to researchers.

2. Every player is unique, so integrating intelligent algorithms might not provide expected results for all as the body and thinking are different foreveryone.

3. All most all the design of wearables with intelligent algorithms is still in development phase, it means they are available in prototypes only. So with only proper validation these prototypes can be brought out as a commercialproduct.

\section{Conclusion}

This paper studies the various intelligent data algorithms proposed and implemented in the field of sports training. With technology the minute details of the game can be perceived. The accuracy and complexity of the models involved in this research vary due to the different classification problems that each model is tasked with. The study observes only few sports are concentrated and research should focus on the design and 
implementation of wearable in other sports also. Moreover the security issues in data handling also have to be considered.

\section{References}

[1] Acikmese Y, Ustundag BC, Golubovic E. Towards an artificial training expert system for basketball. In Proceedings of the $201710^{\text {th }}$ International Conference on Electrical and Electronics Engineering; 2017 Nov 30- Dec 2; Turkey, ELECO; p.1300-1304.

[2] Holzemann A, Van Laerhoven K. Using Wrist-Worn Activity Recognition for Basketball Game Analysis. In Proceedings of the 5th InternationalWorkshoponSensorBasedActivityRecognitionandInteraction.2018Sep20-21;ACMPress:NewYork,NY.p.1-6.

[3] Baumbach S, Bhatt A, Ahmed S, Dengel A. Towards a Digital Personal Trainer for Health ClubsSport Exercise Recognition Using Personalized Models and Deep Learning. In Proceedings of the 10th International Conference on Agents and Artificial Intelligence; 2018 Jan 16-18; Setubal, Portugal. p.438-445.

[4] Das D, Busetty SM, Bharti V, Hegde PK. Strength Training: A Fitness Application for Indoor Based Exercise Recognition and Comfort Analysis. In Proceedings of the 2017 16th IEEE International Conference on Machine Learning and Applications (ICMLA); 2017 Dec 18-21; Cancun, Mexico; p.1126-1129.

[5] Vales-Alonso J, Lopez-Matencio P, Gonzalez-Castano FJ, Navarro-Hellín, H, Banos-Guirao PJ, PerezMartínez FJ, Martinez-Álvarez RP Gonzalez-Jimenez D, Gil-Castineira F, Duro-Fernandez R. Ambient Intelligence Systems for Personalized Sport Training. Sensors. 2010 Mar;10:2359-2385.

[6] Apostolou K, Tjortjis C. Sports Analytics algorithms for performance prediction. In Proceedings of the 2019 10th International Conference on Information, Intelligence, Systems and Applications (IISA); 2019 July 15-17; Patras, Greece; p.1-4.

[7] KampakisS.ComparisonofMachineLearningMethodsforPredictingtheRecoveryTimeofProfessionalFoot ballPlayersafteran Undiagnosed Injury. 2013Sep;1969:58-68.

[8] Blank P, Hobach J, Schuldhaus D, Eskofier BM. Sensor-based stroke detection and stroke type classification in table tennis. In Proceedings of the2015 ACMInternationalSymposiumon WearableComputers-ISWC '15;2015 Sep7-11;Osaka,Japan:ACMPress;p.93-100.

[9] Mora SV, Knottenbelt WJ. Deep Learning for Domain-Specific Action Recognition in Tennis. In Proceedings of the 2017 IEEE Conference on Computer Vision and Pattern Recognition Workshops (CVPRW); 2017 July 21-26; Honolulu, HI, USA; p.170-178.

[10] HolatkaAK, Suwa H, Yasumoto K. Volleyball Setting Technique Assessment Using a Single Point Sensor. In Proceedings of the 2019 IEEE International Conference on Pervasive Computing and Communications Workshops (PerComWorkshops);2019Mar11-15;Kyoto,Japan:p. 567-572.

[11] Crema C, Depari A, Flammini A, Sisinni E, Haslwanter T, Salzmann S. IMU-based solution for automaticdetectionandclassificationofexercisesinthefitnessscenario.InProceedingsoftheIEEESensorsApp lications Symposium(SAS);2017Mar13-15;Glassboro,USA; p.1-6.

[12] Mandot C, Chawla R. Artificial intelligence based integrated cricket coach. In International Conference on Advances in Computing Communication and Control. Springer; 2013 Jan 18-19; Berlin/Heidelberg, Germany; p.227-236.

[13] Somaskandhan P, Wijesinghe G, Wijegunawardana LB, Bandaranayake A, Deegalla S. Identifying the optimal set of attributes that impose high impact on the end results of a cricket match using machine learning. In Proceedings of the IEEE International Conference on Industrial and Information Systems (ICIIS). 2017 Dec 15-16; Peradeniya, Sri Lanka; p.1-6.

[14] Jiao L, Wu, Bie R, Umek A, Kos A. Multi-sensor Golf Swing Classification Using Deep CNN. ProcediaComput. Sci. 2018 Jan; 129:59-65. 